\title{
Histologic Study of Use of Microfibrillar Collagen Hemostat in Rat Dental Sockets
}

\author{
Natasha MAGRO-ÉRNICA \\ Osvaldo MAGRO-FILHO \\ Idelmo RANGEL-GARCIA \\ Department of Oral Surgery and Integrated Clinic, School of Dentistry of Araçatuba, UNESP, Araçatuba, SP, Brazil
}

\begin{abstract}
The aim of this paper was to evaluate if the placement of microfibrillar collagen hemostat (MCH) into a dental socket interfered with healing. General anesthesia was administered to 30 adult male Albinus Wistar rats and the maxillary right central incisor was extracted. In the control group after each tooth was extracted, the socket was sutured. In the MCH group after each tooth was extracted, MCH was placed into the socket before suturing. Postoperatively, 5 animals were sacrificed from each group at 7, 21 and 28 days. The right maxilla was removed from each animal and histologic slides were stained with Masson's trichromic and hematoxylin and eosin. Quantitative and qualitative analyses were done. The percentage of bone area in the dental socket was quantified using the Image Lab 98 image analysis system. The bone area formation for the control and $\mathrm{MCH}$ groups was: $8.1 \%$ and $3.3 \%$ at 7 days, 34.4\% and 33\% at 21 days and $41 \%$ and $41.3 \%$ at 28 days, respectively. We concluded that $\mathrm{MCH}$ interferes with the beginning of dental socket healing but does not interfere with the final healing of the dental socket.
\end{abstract}

Key Words: tooth extraction, hemostat, bleeding, dental socket.

\section{INTRODUCTION}

Microfibrillar collagen hemostat $(\mathrm{MCH})$ is a topical agent composed of resorbable microfibrillar collagen prepared to preserve the native bovine collagen molecules. The $\mathrm{MCH}$ attracts platelets and allows for the formation of a blood clot when it comes into contact with blood (1).

The manufacturer (MedChem Products Inc., Woburn, MS) suggests the use of MCH Avitene to achieve hemostasis with or without conventional methods or in situations in which conventional methods are not practical. This hemostatic agent is contraindicated as the sole hemostatic control in patients who have systemic problems causing hemorrhage.

To date, there is no experimental research in the literature relating the wound healing of a dental socket to $\mathrm{MCH}$. The aim of this study was to determine whether or not the placement of $\mathrm{MCH}$ into a dental socket interferes with socket healing.

\section{MATERIAL AND METHODS}

Thirty male albino rats (Ratus albinus norvegicus, Wistar) weighing 160-220 $\mathrm{g}$ were used in this study. After general anesthesia $(30 \mathrm{mg} / \mathrm{kg}$ thionembutal; Abbott do Brasil, Sao Paulo, SP, Brazil), the maxillary right central incisor was extracted using specially designed instruments (2). The control group consisted of 15 animals that did not receive any treatment to their dental sockets. The MCH group consisted of 15 animals that had MCH (Avitene; MedChem Products Inc., Woburn, MS) placed in the apical and middle thirds of their dental sockets, using a small adapted instrument. Each dental socket of both groups was sutured with 50 vicryl (Ethicon; Johnson \& Johnson do Brasil, São Jose dos Campos, SP, Brazil). Five animals from each group were sacrificed at postoperative days 7, 21 and 28. The right maxilla was separated using a median sagittal incision. The specimen containing the right socket was removed with straight scissors, cutting tan- 
gentially to the distal surface of the last molar.

The specimens were fixed in $10 \%$ formalin for $24 \mathrm{~h}$, decalcified in formic acid and sodium citrate solution, clarified and embedded in paraffin so the sockets could be cut in a longitudinal plane (3). The blocks were semi-serially sectioned at $6 \mu \mathrm{m}$ thickness and the sections were stained with Masson's trichromic and hematoxylin and eosin.

Qualitative and quantitative analyses of bone formation were done. The percentage of bone area in each dental socket was quantified using the IMAGE LAB 98 image analysis system. Data were analyzed with the Tukey test and analysis of variance.

\section{RESULTS}

\section{Qualitative Analysis}

Control Group: After 7 days, the alveolus was partially filled with newly formed connective tissue, blood clot and showed thin osseous trabeculae principally in the apical third (Figure 1). On day 21, the alveolus exhibited thick osseous trabeculae and some areas of mature connective tissue (Figure 2). On day 28, the alveolus was filled with mature osseous trabeculae (Figure 3).

MCH Group: At day 7, osteoid tissue and thin osseous trabeculae were present at the apical third. There was part of the MCH material in some samples (Figure 4) and polymorphonuclear neutrophil infiltration. Thick osseous trabeculae were present at the apical and middle thirds at 21 days (Figure 5). The mature osseous trabeculae present on the 28th day filled almost all alveoli (Figure 6).

\section{Quantitative Analysis}

The quantification of the trabecular bone area in the dental sockets was done by carefully following all of the dental sockets linearly. The mean percentile values of trabecular bone area in the dental socket at 7 , 21 and 28 days were: control group: $8.1 \%, 34.4 \%$ and $41.0 \%$, respectively; $\mathrm{MCH}$ group: $3.3 \%, 33.0 \%$ and $41.3 \%$, respectively.

The Tukey test was applied and the interaction values were then subjected to analysis of variance. There was a significant statistical difference between the experimental and the control groups only at postop- erative day 7 and no significant statistical difference between the groups at postoperative days 21 and 28 .

\section{DISCUSSION}

It is well-documented that $\mathrm{MCH}$ has local hemostatic action. Kubo et al. (4) placed it in contact with bleeding surfaces after great vessel hemostasis during urologic surgery. They concluded the material quickly controlled hemorrhage in all of the patients studied. Low et al. (5) used $\mathrm{MCH}$ in laparoscopy because of its effectiveness as a hemostatic agent. Nakamura et al. (6) used $\mathrm{MCH}$ on the brain cortex and reported that the hemostatic action was $95 \%$ effective without any side effects in all of their experimental surgeries. Low et al. (5) and Nakamura et al. (6) concluded that $\mathrm{MCH}$ is biocompatible in their areas of research. The dental socket, however, presents its own peculiarities when compared with other areas of the body (7).

An in vitro coagulation mechanism of commercialized products was evaluated by Wagner et al. (8). They classified from better to worse the following hemostatic agents: microfibrillar collagen (Avitene $\left.{ }^{\circledR}\right)$, collagen sponges (Helistat ${ }^{\circledR}$, Instat ${ }^{\circledR}$ and Actifoam $\left.{ }^{\circledR}\right)$, gelatin sponge $\left(\right.$ Gelfoam $\left.^{\circledR}\right)$ and oxidized regenerated cellulose (Surgicel ${ }^{\circledR}$ ). As a result, the use of $\mathrm{MCH}$ for postoperative bleeding in dental sockets appears to be an interesting option. The aim of this paper was not to evaluate hemostasis; however, we did notice that the $\mathrm{MCH}$ group did not show the same amount of bleeding as the control group.

Barbolt et al. (9) carried out a comparative study with gelatin sponge, oxidized regenerated cellulose and $\mathrm{MCH}$ implanted in the subdural space after craniotomy in rabbits. They reported that the tissue reaction to $\mathrm{MCH}$ was characterized by moderate to marked granulomatous inflammation with an acute inflammatory component indicating a greater degree of tissue irritation. Sequelae of this reaction were still observed at 92 days post-implantation.

A question that still remains is: can $\mathrm{MCH}$ be used in the dental socket after tooth extraction? It is believed that the majority of materials implanted in the dental socket after dental extraction to treat alveolitis, to avoid alveolus atrophy or to act as a hemostatic agent all promote considerable healing delay (10). We agree with Perri de Carvalho and 


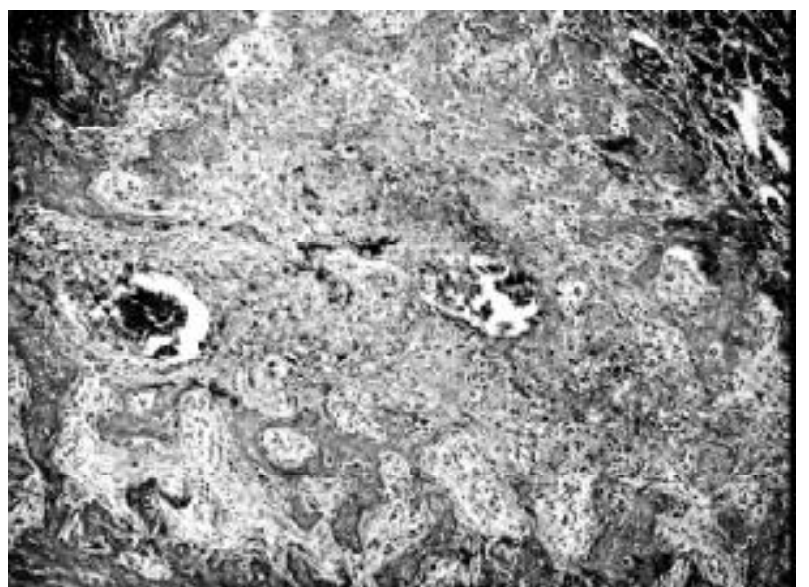

Figure 1. Control Group. 7 days postoperative. Newly formed connective tissue, blood clot and thin osseous trabeculae in the apical third. H\&E. Original magnification, 63X.

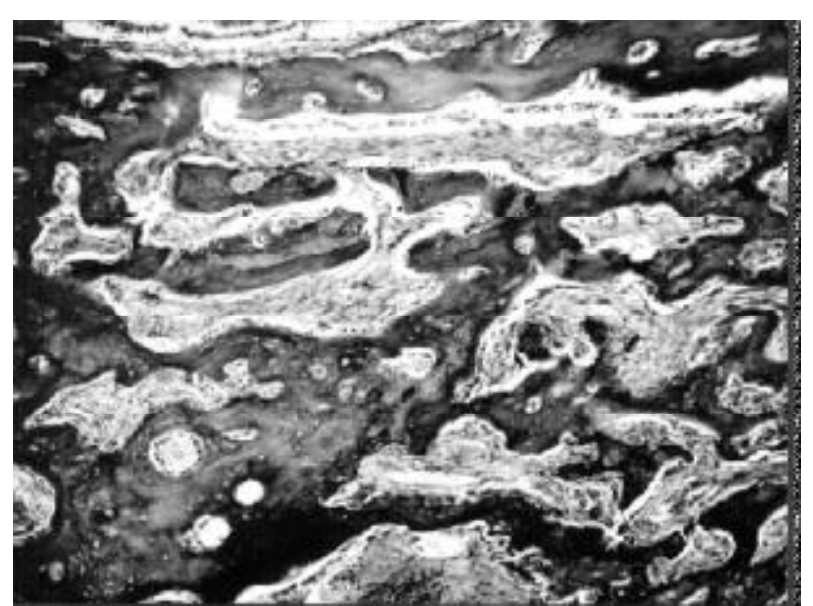

Figure 2. Control Group. 21 days postoperative. Presence of thick osseous trabeculae and some areas of mature connective tissue. H\&E. Original magnification, 63X.

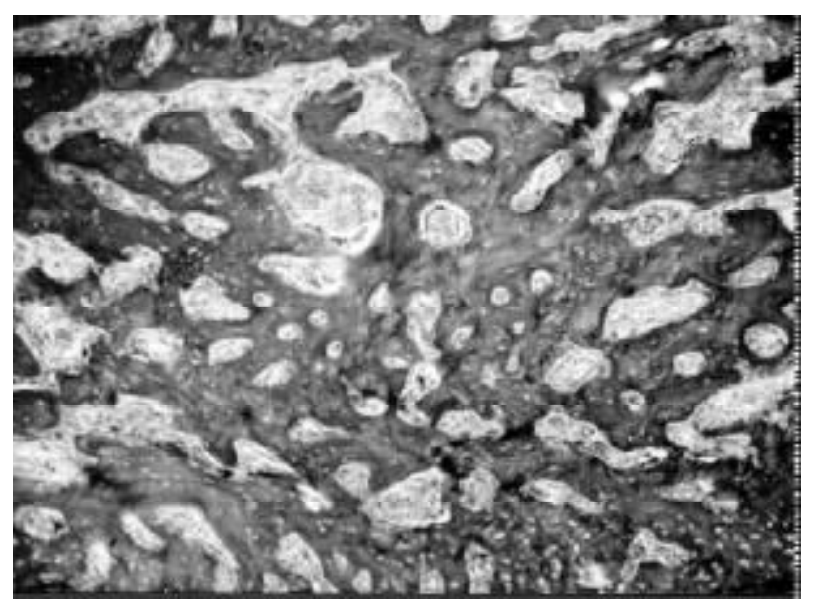

Figure 3. Control Group. 28 days postoperative. Mature osseous trabeculae in the dental alveolus. H\&E. Original magnification, 63X.

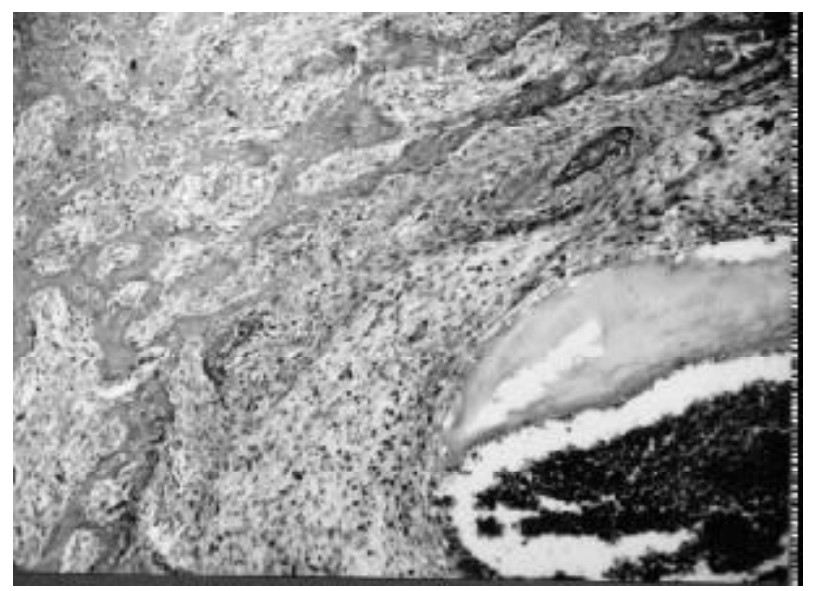

Figure 4. MCH Group. 7 days postoperative. Connective tissue, osteoid tissue and thin osseous trabeculae in the apical third. $\mathrm{MCH}$ material is still present. H\&E. Original magnification, 63X.

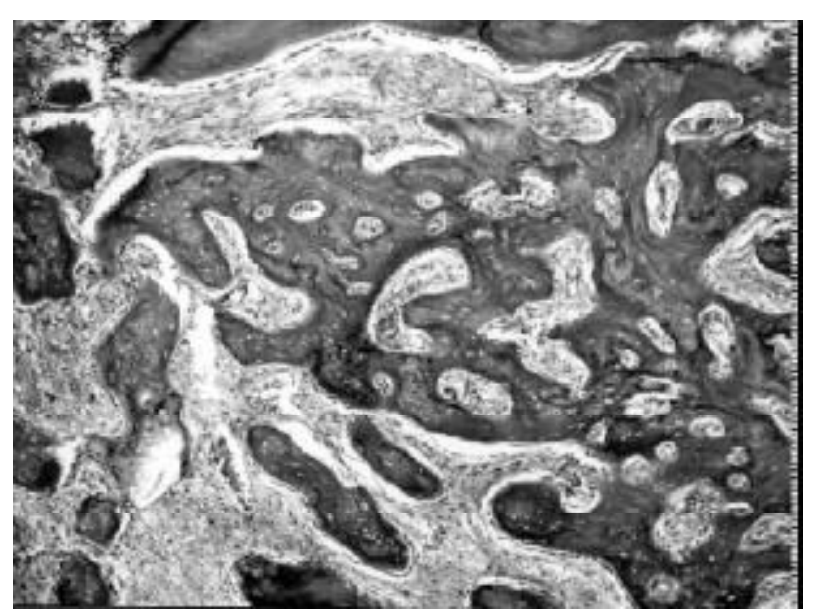

Figure 5. MCH Group. 21 days postoperative. The apical third presents a thick osseous trabeculae. H\&E. Original magnification, $63 \mathrm{X}$.

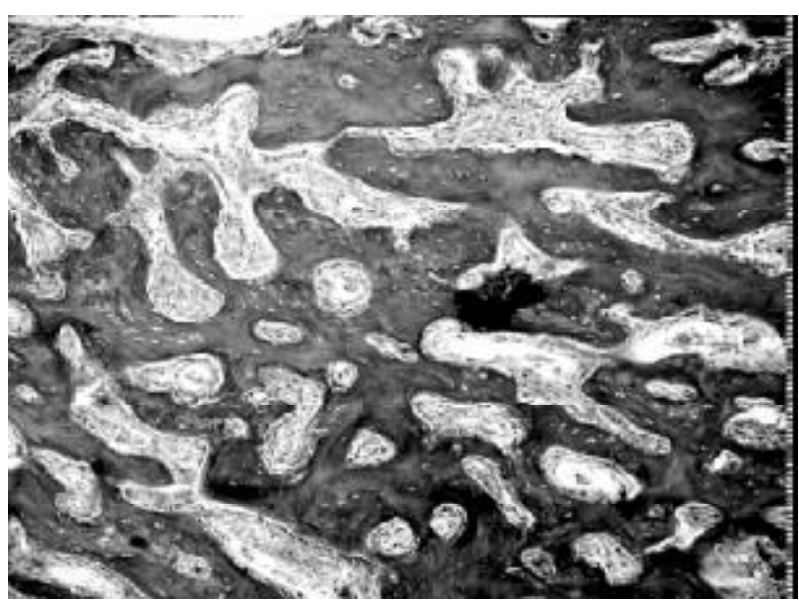

Figure 6. MCH Group. 28 days postoperative. Mature osseous trabeculae fills the alveolus. H\&E. Original magnification, 63X. 
Okamoto (7) who reported after numerous studies that the use of materials in the dental socket should be restricted to those cases in which the need for hemostasis outweighs the potential morbidity.

In our study, $\mathrm{MCH}$ was not totally absorbed at 7 days postoperatively and there was formation of thin trabeculae bone in the apical third of the alveolus; however, the control group showed a greater quantity of new bone at 7 days, most likely due to the presence of $\mathrm{MCH}$ in the other group. The final healing quality, however, was similar in both groups. The initial interference of $\mathrm{MCH}$ did not influence the quantity of trabecular bone in the dental socket.

We conclude that the hemostatic agent presented here appears to be a viable alternative in controlling intraoperative and postoperative hemorrhage from the dental alveolus because it is both biocompatible and effective.

\section{ACKNOWLEDGMENTS}

This study was supported by CNPq. The authors wish to thank Dr. Tetuo Okamoto for his assistance with the histological analysis and Dr. Eloi Dezan Jr. for his assistance with the statistical analysis (School of Dentistry of Araçatuba, UNESP, Brazil).

\section{RESUMO}

O objetivo deste trabalho é avaliar se a colocação do $\mathrm{MCH}$ no interior do alvéolo dental interfere ou não no reparo alveolar. Foi feita anestesia geral nos trinta ratos machos adultos Albinus Wistar e o incisivo central superior direito foi extraído. No grupo controle, após a exodontia o alvéolo foi suturado. No grupo $\mathrm{MCH}$, após a exodontia introduziu-se $\mathrm{MCH}$ dentro do alvéolo que foi suturado. No pós-operatório, cinco animais de cada grupo foram sacrificados aos 7, 21 e 28 dias. Retirou-se a maxila direita de cada animal e cortes histológicos foram confeccionados. Foi feita análise qualitativa e quantitativa. A porcentagem de área óssea no interior dos alvéolos dentais foi quantificada usando o sistema de análise de imagens ImageLab 98. A área óssea neoformada no grupo controle e no grupo $\mathrm{MCH}$ foi: $8.1 \%$ e $3.3 \%$ aos 7 dias, $34.4 \%$ e $33 \%$ aos 21 dias e $41 \%$ e $41.3 \%$ aos 28 dias respectivamente. Dentro das condições experimentais deste trabalho foi possível concluir que o $\mathrm{MCH}$ interfere durante o início do reparo alveolar e não interfere no reparo final do alvéolo dental.

\section{REFERENCES}

1. Nakajima M, Kamei T, Tomimatu K, Manabe T. An intraperitoneal tumorous mass caused by granulomas of microfibrillar collagen hemostat (Avitene). Arch Pathol Lab Med 1995;119:11611163.

2. Okamoto T, Russo MC. Wound healing following tooth extraction. Histochemical study in rats. Rev Fac Odont Araçatuba 1973;2:153-169.

3. Morse A. Formic acid sodium citrate descalcification and butyl alcohol deydration of teeth and bone for sectioning in paraffin. $\mathrm{J}$ Dent Res 1945;24:143.

4. Kubo S, Ishibashi A, Koshiba K. Clinical studies on topical hemostat. Avitene in urological surgery. Hinyokika Kiyo 1984:30:131-134.

5. Low RK, Moran ME, Goodnight JE. Microfibrillar collagen hemostat during laparoscopically direct liver biopsy. J Laparoendosc Surg 1993;3:415-420.

6. Nakamura N, Hashimoto T, Sakai H, Yasue S, Nagayama I, Sasaki T, Basugi N, Kim K, Kitamura K, Yoshimasu M. Clinical application of microfibrillar collagen hemostat (Avitene) in neurosurgical field. No Shinkei Geka 1998;16:933-938.

7. Perri de Carvalho AC, Okamoto T. Cirurgia Bucal, Fundamentos Experimentais Aplicados à Clínica. 1st ed. São Paulo: Editora Panamericana, 1987.

8. Wagner WR, Pachence JM, Ristich J, Johnson PC. Comparative in vitro analysis of topical hemostatic agents. J Surg Res 1996;66:100-108.

9. Barbolt TA, Odin M, Kangas L. Pre-clinical subdural tissue reaction and absorption study of absorbable hemostatic devices. Neurol Res 2001;23:537-542.

10. Carvalho ACP, Okamoto T. Implantes intra-alveolares Considerações sobre estudos experimentais. Rev Ass Paul Cirurg Dent 1978;32:11-15. 